\section{Temperature Influences Nitrogen Release Rates in Cranberry Soils}

\author{
Joan R. Davenport ${ }^{1}$ \\ Department of Crop and Soil Sciences, Washington State University, 24106 \\ N. Bunn Road, Prosser, WA 99350
}

Carolyn DeMoranville

University of Massachusetts-Amherst, Cranberry Experiment Station, P.O. Box 569, E. Wareham, MA 02538

Additional index words. Vaccinium macrocarpon, $\mathrm{pH}$, acid soils, organic matter, peat, organic soils

\begin{abstract}
Native nitrogen is released when soils are mineralized. The amount of $\mathrm{N}$ released by this process depends on the amount of organic matter present and soil temperature. Cranberry (Vaccinium macrocarpon Ait.) grows in acidic soils with a wide range in organic matter content. To evaluate release of cranberry soil $\mathrm{N}$ at varied soil temperatures, intact soils were collected from sites that had received no fertilizer. Soils were cored and placed in polyvinyl chloride (PVC) columns $20 \mathrm{~cm}$ deep $\times 5 \mathrm{~cm}$ in diameter. Four different soil types, representing the array of conditions in cranberry soil (mineral, sanded organic, organic peat, and muck) were used. Additional columns of sand soil ( $\mathrm{pH} 4.5$ ) that had been pH adjusted to high (6.5) and low (3.0) were also prepared. Each column was incubated sequentially at six different temperatures from 10 to $24^{\circ} \mathrm{C}\left(2.8^{\circ} \mathrm{C}\right.$ temperature intervals $)$ for 3 weeks at each temperature, with the soils leached twice weekly to determine the amount of $\mathrm{N}$ release. The total amount of $\mathrm{N}$ in leachate was highest in the organic soils, intermediate in the sanded organic, and lowest in the sands. At the lowest temperature $\left(10^{\circ} \mathrm{C}\right)$, higher amounts of $\mathrm{N}$ were released in sanded organic and sand than in organic soils. This was attributed to a flush of mineralization with change in the aerobic status and initial soil warming. The degree of decomposition in the organic soils was important in determining which form of $\mathrm{N}$ predominated in the leachate. In the more highly decomposed soil (muck), most of the $\mathrm{N}$ was converted to nitrate. In the $\mathrm{pH}$ adjusted sand, high soil pH (6.5) resulted in an increase in nitrate in the leachate but no change in ammonium when compared to non-adjusted (pH 4.5) and acidified (pH 3.0) treatments. This study suggests that for cranberry soils with organic matter content of at least $1.5 \%$ little to no soil-applied fertilizer $\mathrm{N}$ is needed early in the season, until soil temperatures reach $13{ }^{\circ} \mathrm{C}$. This temperature is consistent with the beginning of active nutrient uptake by roots. Soil $\mathrm{N}$ release from native organic matter was fairly consistent until soil temperatures exceeded $21{ }^{\circ} \mathrm{C}$, indicating that when temperatures exceed $21^{\circ} \mathrm{C}$, planned fertilizer applications should be reduced, particularly in highly organic soils.
\end{abstract}

The American cranberry is a nondeciduous woody perennial that grows in soils ranging from pure sands to pure peat, with a wide range of organic matter content (Davenport and DeMoranville, 1993). Soil organic matter content in the $0-15 \mathrm{~cm}$ rooting depth (Eck, $1990)$ is further modified in some growing regions by the management practice of applying a $1.3-2.6 \mathrm{~cm}$ layer of surface sand every $3-5$ years (Dana, 1990).

Nitrogen management is critical in cranberry crop production. The presence of $\mathrm{N}$, particularly early in the season, can lead to an abundance of vegetative growth at the expense of fruit production (Davenport, 1996; Davenport and Vorsa, 1999; DeMoranville, 1992). Thus, understanding nitrogen mineralization is critical for planning nitrogen fertilizer applica-

Received for publication 22 July 2003. Accepted for publication 10 Sept. 2003. We wish to acknowledge financial support for this project from the Massachusetts Dept. of Food and Agriculture, Ocean Spray Cranberries, Inc., and the Cape Cod Cranberry Growers' Association.

${ }^{1}$ To whom reprint requests should be addressed. E-mail address: jdavenp@wsu.edu tion rates and timing. In addition, nitrogen form is important in cranberry production. Like most ericaceous plants (Korcak, 1989), cranberries preferentially use ammonium nitrogen. Nitrate reductase activity in cranberry is extremely limited (Smith, 1993); thus, nitrate metabolism in cranberry is negligible. This factor, coupled with environmental concerns associated with nitrate in a system with shallow depth to groundwater, results in nitrification being undesirable in the cranberry system.

Previous studies of $\mathrm{N}$ mineralization have focused on mineral soils in $\mathrm{pH}$ ranges that are higher than those typically found in cranberry soils. Studies of N mineralization have involved a number of methods ranging from anaerobic to aerobic incubations in the lab (Griffin and Honeycutt, 2000; McInnes and Fillery, 1989; Smith et al., 1994), intact core incubations with or without leaching (Davidsson and Ståhl, 2000; Franzluebbers et al., 1996; Stenger et al., 1995) to in situ field measurements (Carpenter-Boggs et al., 2000; Chantigny et al., 2002 ; Stenger et al, 1996). Myers et al. (1989) suggest that laboratory incubations of intact cores provide a closer approximation of $\mathrm{N}$ mineralization than using disturbed cores, particularly for situations where the soil is not routinely disturbed by tillage, as is the case for cranberry.

Temperature has long been understood to play a role in $\mathrm{N}$ mineralization. In general, higher soil temperatures are associated with increased mineralization rate (Cassman and Munns, 1980). This has led to an interest in developing degree day-type models for $\mathrm{N} \mathrm{min-}$ eralization of organic amendments (Griffin and Honeycutt, 2000). More recent work looking at the effect of temperature on $\mathrm{N}$ mineralization of organic materials in amended mineral soils has indicated that slight amounts of mineralization can occur during near-freezing temperatures (Chantigny et al., 2002.)

The objective of this study was to determine the mineralization and nitrification potential of organic nitrogen in cranberry soils over the range of soil temperatures that occur in a producing cranberry bed during the growing season. Cranberry soil acidity results in a much lower $\mathrm{pH}$ range than is typical in other agricultural production soils. The data presented here show changes in $\mathrm{N}$ release associated with increasing soil temperature in these low pH soils.

\section{Materials and Methods}

Cranberry soils, collected in early spring of 1996, were chosen to represent the range of soil types in producing cranberries in the United States. Sand used to develop new cranberry plantings (cultivated Psamments) and a sanded organic soil (Swansea coarse sand, modified sandy, mixed, dystic, mesic, Terric Medisaprist) were collected in Lakeville, Mass. Respectively, these represent a typical, recently developed mineral soil planting and a long-term cultivated and sanded cranberry soil (sanded organic). We also collected the highly decomposed Seastrand muck (dystic, mesic, typic Medihemist) and the less decomposed Bestpitch peat (clayey, mixed, euic, mesic, Terric Sulfihemist) from Grayland, Wash., and Chatsworth, N.J., respectively.

Intact blocks of soils were collected from the field. The soils were cored and fitted to 20-cm-deep, 30-cm-long, 5-cm-diameter split PVC columns with the sides and bottom sealed, leaving an egress tube for water flow out of the column (Davenport et al., 1994). Seven columns of each soil type were prepared; two columns were frozen to preserve for later analysis and the remaining five were prepared for leaching.

Fourteen additional columns of the Psamment (sand soil) were prepared, seven each with the $\mathrm{pH}$ adjusted to 3.0 with the addition of sulfuric acid and seven with the $\mathrm{pH}$ adjusted to 6.5 with the addition of calcium carbonate $\left(\mathrm{CaCO}_{3}\right)$; five of each column type were used for leaching and two frozen for later analysis. To determine the amount of sulfuric acid and calcium carbonate to add, 100-g samples of sand were weighed into beakers. A $10 \%$ sulfuric acid solution in a series of $10-\mathrm{mL}$ increments or reagent grade $\mathrm{CaCO}_{3}$ in 5-g increments were added to the sand (each treatment replicated 3 times). The soils were wetted with 
$50 \mathrm{~mL}$ water (or water and acid), stirred, and allowed to equilibrate for $3 \mathrm{~d}$. Soil $\mathrm{pH}$ was then determined and appropriate amendment rate chosen. Soils for the columns were then mixed in bulk with the selected rates of $\mathrm{CaCO}_{3}$ or $10 \%$ sulfuric acid, packed into the columns, wetted, and handled similarly to the unadjusted columns.

Leaching columns were placed in a controlled temperature room at $10^{\circ} \mathrm{C}$ and allowed to equilibrate for 1 week. Once equilibrated, the soils were leached every 3-4 d (twice weekly) with 1 pore volume equivalent of distilled, deionized water. Leachate samples were collected prior to each water addition and stored at $4{ }^{\circ} \mathrm{C}$ for analysis. Columns were incubated sequentially at six temperatures from 10 to $24^{\circ} \mathrm{C}\left(2.8^{\circ} \mathrm{C}\right.$ increments $)$. During each incubation, columns were leached for up to $21 \mathrm{~d}$. One week with no water addition was allowed for soil temperature equilibration between each temperature exposure.

After leaching was completed, the soil columns (both leached and frozen control) were separated into four 5-cm depths. Soil samples were analyzed for total soil organic carbon (Ben-Dor and Banin, 1989), total Kjeldahl nitrogen (Issac and Johnson, 1976), ammonium and nitrate nitrogen (Lachat Instruments, 1995; Ruzicka, 1983), soil pH (1:1 by weight in DI $\mathrm{H}_{2} \mathrm{O}$ ), and particle size distribution (percent sand, silt, clay) of the mineral fraction (Miller and Miller, 1987) (Table 1). Total volume of the leachate samples was measured and the samples analyzed colorimetrically for ammonium and nitrate nitrogen (Environmental Protection Agency, 1984a, 1984b).

The total amount of nitrate or ammonium nitrogen released was calculated from the analyte content of the leachate and the volume of the leachate. Total plant available nitrogen (TN) was calculated by addition of the two soluble $\mathrm{N}$ forms. Statistical analysis of the data was conducted by analysis of variance and regression modeling using PROC GLM of PC SAS (SAS Institute, Cary, N.C.).

Three soil subsamples were collected from control and leached sand columns that were $\mathrm{pH}$ adjusted. These samples were then used to assess the populations of the two bacteria species associated with the nitrification process, Nitrobacter sp. and Nitrosamonus sp. (nitrifying bacteria), using a most probable numbers method(MPN; Schmidt and Belser, 1994). This method involves making serial dilutions of the soil, which are then used to inoculate medium containing ammonium and an indicator dye. If the organisms are present, the ammonium is oxidized and $\mathrm{pH}$ of the medium changes, leading to a color change in the medium.

\section{Results and Discussion}

Average daily nitrogen release varied by soil, temperature, and the interaction of the two (Table 2 ). The soil $\times$ temperature interaction is reflected in the varied patterns of $\mathrm{N}$ release in each soil as temperature varied. The soils with mineral surface horizons - Psamment and Swansea coarse sand - had initial flushes of N released at the lowest temperature. Nitrogen

Table 1. Selected characteristics of soils, evaluated after leaching (data are the means of five replicates).

\begin{tabular}{lrccccc}
\hline Soil & $\begin{array}{c}\text { Depth } \\
(\mathrm{cm})\end{array}$ & $\begin{array}{c}\text { Organic carbon } \\
(\%)\end{array}$ & $\mathrm{pH}$ & Sand & Silt & Clay \\
\hline \multirow{3}{*}{ Psamment } & & & & $--------------\%$----------- \\
& $0-5$ & 0.33 & 4.89 & 96.87 & 0.38 & 2.41 \\
& $5-10$ & 0.38 & 4.93 & 96.88 & 0.43 & 2.30 \\
Swansea coarse & $10-15$ & 0.36 & 4.79 & 96.85 & 0.32 & 2.47 \\
sand & $15-20$ & 0.40 & 5.54 & 97.71 & 0.19 & 1.69 \\
& $0-5$ & 3.51 & 4.56 & 95.03 & 0.23 & 1.24 \\
& $5-10$ & 2.47 & 4.52 & 96.04 & 0.46 & 1.02 \\
Bestpitch peat & $10-15$ & 2.43 & 4.50 & 95.78 & 0.91 & 0.85 \\
& $15-20$ & 5.17 & 4.57 & 92.52 & 1.76 & 0.54 \\
& $0-5$ & 14.71 & 3.83 & 83.84 & 1.27 & 0.18 \\
Seastrand muck & $5-10$ & 14.88 & 4.41 & 83.73 & 1.01 & 0.38 \\
& $10-15$ & 13.05 & 4.62 & 86.08 & 0.73 & 0.15 \\
& $15-20$ & 5.08 & 4.24 & 93.84 & 0.90 & 0.18 \\
& $0-5$ & 20.70 & 3.91 & 79.04 & 0.00 & 0.26 \\
& $5-10$ & 19.98 & 4.26 & 79.83 & 0.04 & 0.15 \\
& $10-15$ & 19.41 & 4.29 & 80.46 & 0.13 & 0.00 \\
& $15-20$ & 19.90 & 4.32 & 79.87 & 0.23 & 0.00 \\
\hline
\end{tabular}

Table 2. Average daily nitrogen release $\left[\mathrm{NH}_{4}-\mathrm{N}, \mathrm{NO}_{3}-\mathrm{N}\right.$ and total soluble $\mathrm{N}$ $(\mathrm{TN})]$ across a $15-18 \mathrm{~d}$ period.

\begin{tabular}{|c|c|c|c|c|}
\hline Soil & Temp & $\mathrm{TN}$ & $\mathrm{NH}_{4}-\mathrm{N}$ & $\mathrm{NO}_{3}-\mathrm{N}$ \\
\hline & & ---------- & $--\mathrm{kg} \cdot \mathrm{ha}^{-1}$ & ------- \\
\hline \multirow[t]{6}{*}{ Psamment } & 10.0 & $2.36 \mathrm{a}^{\mathrm{z}}$ & $0.73 \mathrm{a}$ & $1.63 \mathrm{a}$ \\
\hline & 12.8 & $0.25 \mathrm{~b}$ & $0.16 \mathrm{~b}$ & $0.09 \mathrm{~b}$ \\
\hline & 15.6 & $0.42 \mathrm{~b}$ & $0.32 \mathrm{ab}$ & $0.10 \mathrm{~b}$ \\
\hline & 18.4 & $0.21 \mathrm{~b}$ & $0.12 \mathrm{~b}$ & $0.09 \mathrm{~b}$ \\
\hline & 21.2 & $0.17 \mathrm{~b}$ & $0.14 \mathrm{~b}$ & $0.03 \mathrm{~b}$ \\
\hline & 24.0 & $0.26 \mathrm{~b}$ & $0.17 \mathrm{~b}$ & $0.09 \mathrm{~b}$ \\
\hline \multirow{6}{*}{$\begin{array}{l}\text { Swansea coarse } \\
\text { sand }\end{array}$} & 10.0 & $9.14 \mathrm{a}$ & $1.92 \mathrm{a}$ & $7.22 \mathrm{a}$ \\
\hline & 12.8 & $5.03 \mathrm{ab}$ & $0.09 \mathrm{~b}$ & $4.94 \mathrm{ab}$ \\
\hline & 15.6 & $3.59 \mathrm{ab}$ & $0.25 \mathrm{ab}$ & $3.34 \mathrm{ab}$ \\
\hline & 18.4 & $2.96 \mathrm{~b}$ & $0.59 \mathrm{ab}$ & $2.37 \mathrm{~b}$ \\
\hline & 21.2 & $3.70 \mathrm{~b}$ & $0.30 \mathrm{ab}$ & $3.40 \mathrm{ab}$ \\
\hline & 24.0 & $5.22 \mathrm{ab}$ & $0.18 \mathrm{~b}$ & $5.03 \mathrm{ab}$ \\
\hline \multirow[t]{6}{*}{ Bestpitch peat } & 10.0 & $3.54 \mathrm{c}$ & $1.19 \mathrm{c}$ & $2.35 \mathrm{c}$ \\
\hline & 12.8 & $1.76 \mathrm{c}$ & $0.80 \mathrm{c}$ & $0.96 \mathrm{c}$ \\
\hline & 15.6 & $2.04 \mathrm{c}$ & $0.74 \mathrm{c}$ & $1.30 \mathrm{c}$ \\
\hline & 18.4 & $3.91 \mathrm{bc}$ & $1.07 \mathrm{c}$ & $2.84 \mathrm{c}$ \\
\hline & 21.2 & $19.72 \mathrm{~b}$ & $5.29 \mathrm{~b}$ & $14.43 \mathrm{~b}$ \\
\hline & 24.0 & $64.70 \mathrm{a}$ & $27.99 \mathrm{a}$ & $36.71 \mathrm{a}$ \\
\hline \multirow[t]{6}{*}{ Seastrand muck } & 10.0 & $12.65 \mathrm{a}$ & $0.09 \mathrm{bc}$ & $12.56 \mathrm{a}$ \\
\hline & 12.8 & $9.72 \mathrm{a}$ & $0.05 \mathrm{c}$ & $9.67 \mathrm{a}$ \\
\hline & 15.6 & $13.72 \mathrm{a}$ & $0.09 \mathrm{bc}$ & $13.63 \mathrm{a}$ \\
\hline & 18.4 & $12.29 \mathrm{a}$ & $0.16 \mathrm{ab}$ & $12.13 \mathrm{a}$ \\
\hline & 21.2 & $13.92 \mathrm{a}$ & $0.22 \mathrm{a}$ & $13.70 \mathrm{a}$ \\
\hline & 24.0 & $20.29 \mathrm{a}$ & $0.02 \mathrm{c}$ & $20.27 \mathrm{a}$ \\
\hline \multicolumn{5}{|c|}{ Significance from analysis of variance } \\
\hline Soil type $(\mathrm{S})$ & & $* * *$ & $* * *$ & $* * *$ \\
\hline Temperature (T) & & $* * *$ & $* * *$ & $* * *$ \\
\hline $\mathrm{S} \times \mathrm{T}$ & & $* * *$ & $* * *$ & $* * *$ \\
\hline
\end{tabular}

release declined in these soils as temperature increased, with the exception of the highest temperature in the Swansea soil. The relatively high $\mathrm{N}$ release at low soil temperatures in the mineral soils may be related to conditions surrounding soil management. With the exception of the Pacific Northwest, during the dormant winter period, cranberry soils are flooded to protect the plants from winter injury (DeMoranville, 1997). Hanlon et al. (1997) found increased nitrogen mineralization when soils move from anaerobic to aerobic conditions. The high rate of $\mathrm{N}$ release for the $10{ }^{\circ} \mathrm{C}$ incu- bation likely reflects the shift in soil aeration status, since the soils were collected in the early spring, while they were still anaerobic, and were brought to aerobic conditions during temperature equilibration prior to the initiation of leaching.

Nitrogen release patterns widely differed between the two organic soils. Nitrogen release in the Bestpitch peat was low until the temperature exceeded $18.4^{\circ} \mathrm{C}$. Above this temperature, $\mathrm{N}$ release increased; both $\mathrm{NO}_{3}-\mathrm{N}$ and $\mathrm{NH}_{4}-\mathrm{N}$ followed this pattern. In the Seastrand muck, $\mathrm{TN}$ and $\mathrm{NO}_{3}-\mathrm{N}$ were consistently high at all 
temperatures. $\mathrm{NH}_{4}-\mathrm{N}$ release in this soil was variable but contributed little to the total $\mathrm{N}$ recovered (Table 2).

Overall, accumulation of $\mathrm{NO}_{3}-\mathrm{N}$ in the leachate was higher than that of $\mathrm{NH}_{4}-\mathrm{N}$. This indicates that most of the mineralized soil nitrogen was converted to nitrate in the 3-4 d period between each leaching. The conversion from $\mathrm{NH}_{4}-\mathrm{N}$ to $\mathrm{NO}_{3}-\mathrm{N}$ is not desirable in the cranberry system. The Psamment and Swansea soils, which both are effectively mineral soils in the $20-\mathrm{cm}$ soil depth of this study, retained $10 \%$ to $35 \%$ of released $\mathrm{N}$ as $\mathrm{NH}_{4}$. The two organic soils had widely differing distributions of $\mathrm{N}$ forms. Virtually all $\mathrm{N}$ released in the Seastrand muck was found as $\mathrm{NO}_{3}^{-}$, whereas in the Bestpitch peat over $35 \%$ was $\mathrm{NH}_{4}^{+}$. This may reflect differences in soil water management as well as in microbial populations. Since these soils have been put into cranberry production, flooding has not been used on the Seastrand muck as a management practice, whereas the Bestpitch peat has been flooded twice annually, with an annual cumulative total of 5 months under water. The higher degree of decomposition in the Seastrand muck implies that greater microbial mineralization has occurred in that soil, which could have resulted in increased populations of nitrifying bacteria that appear to be active over a range of temperatures. This, plus increased nitrification associated with drained organic soils (Hanlon et al., 1997), would account for the apparently rapid and nearly complete nitrification of $\mathrm{NH}_{4}-\mathrm{N}$.

In columns of sand soil where $\mathrm{pH}$ was adjusted, both soil nitrogen and nitrifying bacteria populations were related to soil $\mathrm{pH}$. The cumulative amount of total soluble $\mathrm{N}$ and $\mathrm{NO}_{3}-\mathrm{N}$ were significantly higher in the $\mathrm{pH} 6.5$ sand than when $\mathrm{pH}$ was 4.5 or 3.0 (Table 3 ), but $\mathrm{NH}_{4}-\mathrm{N}$ was not influenced. After the leaching series, there was a significantly higher population of nitrifying bacteria in the $\mathrm{pH} 6.5$ sand than in the initial (frozen) soil or in the low $\mathrm{pH}$ soil (Table 4).

To apply this information to $\mathrm{N}$ management in cranberry production, soil and temperature factors were evaluated to determine if they could be used to predict seasonal $\mathrm{N}$ availability. $\mathrm{N}$ release at $10{ }^{\circ} \mathrm{C}$ in the mineral soils used in this study may reflect the influence of factors other than temperature, such as $\mathrm{N}$ accumulation in the soils during flooded conditions prior to collection (Hanlon et al., 1997). Hence, all $10^{\circ} \mathrm{C}$ data were excluded from this analysis. Using data from the 12.8 to $24^{\circ} \mathrm{C}$ temperature range, $\mathrm{TN}$ ( $\mathrm{kg} /$ day) could be predicted from

Table 3. Average cumulative total soluble nitrogen, ammonium $\left(\mathrm{NH}_{4}-\mathrm{N}\right)$ and nitrate $\left(\mathrm{NO}_{3}-\mathrm{N}\right)$ nitrogen content in leachate from sand soils with medium (unadjusted) $\mathrm{pH}$ (4.5) or with adjusted high (6.5) or low (3.0) pH.

\begin{tabular}{|c|c|c|c|}
\hline Soil pH & Total N & $\mathrm{NH}_{4}-\mathrm{N}$ & $\mathrm{NO}_{3}-\mathrm{N}$ \\
\hline & \multicolumn{3}{|c|}{---------------- ppm -------------- } \\
\hline High & $56.60 \mathrm{a}^{2}$ & $6.38 \mathrm{a}$ & $50.22 \mathrm{a}$ \\
\hline Medium & $10.34 \mathrm{~b}$ & $3.89 \mathrm{a}$ & $6.45 \mathrm{~b}$ \\
\hline Low & $14.07 \mathrm{~b}$ & $5.46 \mathrm{a}$ & $8.61 \mathrm{~b}$ \\
\hline
\end{tabular}

${ }^{\mathrm{z}}$ Means separation within columns by least significant differences at $P<0.05$. soil temperature $\left(\mathrm{T}\right.$, in $\left.^{\circ} \mathrm{C}\right)$, percent soil organic carbon (OC), and percent clay (C) in the soil by the following equation $\left(\mathrm{df}=97 ; R^{2}=0.389\right.$; $\left.\mathrm{F}=19.93^{* * * *}\right)$ :

$$
\mathrm{TN}=-21.42+1.63 \mathrm{~T}+0.48 \mathrm{OC}-4.38 \mathrm{C}
$$

This relationship indicates that the total $\mathrm{N}$ released will increase with increasing soil temperature or soil organic carbon content. However, as reflected by the low $R^{2}$ value, we recognize that other unmeasured factors contribute to total $\mathrm{N}$ released from soils. The soil organic carbon content reflects the different soil series studied (Table 1), which represent the range of organic carbon content found in cranberry soils in North America (Davenport and DeMoranville, 1993). The equation also predicts that the total $\mathrm{N}$ released by a soil will be decreased as the soil clay content increases. Traditional cranberry soils typically contain very little clay (Davenport and DeMoranville, 1993). However, in considering sites for new plantings, this factor should be considered.

The proportion of $\mathrm{TN}$ in the $\mathrm{NH}_{4}-\mathrm{N}$ form $\left(\mathrm{PNH}_{4}\right)$ can be described by the equation ( $\mathrm{df}$ $\left.=97 ; R^{2}=0.379 ; \mathrm{F}=12.85^{* * * *}\right)$ :

$$
\begin{aligned}
\mathrm{PNH}_{4}= & 1.51-0.011 \mathrm{~T}-0.117 \mathrm{pH} \\
& +0.294 \mathrm{C}+0.295 \mathrm{Sl}-0.022 \mathrm{~S}
\end{aligned}
$$

where $\mathrm{pH}, \mathrm{Sl}$, and $\mathrm{S}$ are soil $\mathrm{pH}$, percent silt, and percent sand, respectively. The decrease in the $\mathrm{PNH}_{4}$ with temperature likely reflects an increase in nitrification of $\mathrm{N}$ as temperatures increase. Likewise, $\mathrm{PNH}_{4}$ decreases with increasing soil $\mathrm{pH}$, likely due to increases in the population of nitrifiers as soil $\mathrm{pH}$ increases (Table 4). The negative relationship between $\mathrm{pH}$ and the $\mathrm{PNH}_{4}$ indicates that lowering $\mathrm{pH}$ could have a positive impact on plant available $\mathrm{N}$ in the cranberry system. Cranberry soils are naturally acidic. However, cultural practices in some cranberry production areas have resulted in a trend towards increased soil $\mathrm{pH}$ over the past 30 years (DeMoranville, 1990). Reduction of soil $\mathrm{pH}$ may be necessary for cranberry production, particularly on highly organic soils, and could be advantageous for cranberry $\mathrm{N}$ management.

Soil temperature influences cranberry soil $\mathrm{N}$ release. However, other factors, including flood cycles that change soil aerobic status, organic matter content, and the degree of decomposition of the organic matter mitigate the temperature response. Organic soils sup-

Table 4. Population estimates of nitrifying bacteria in sand soils using most probable numbers (MPN) technique. Soil $\mathrm{pH}$ was either adjusted to high (6.0) or low (3.0) levels prior to leaching or holding as controls (frozen). Values are average of two columns for controls and five columns for leached. Control values represent microbial populations prior to incubation and leaching.

\begin{tabular}{lcc}
\hline & $\begin{array}{c}\text { Avg population } \\
\text { bacterial cells/ } \\
\text { mL soil extract }\end{array}$ & $95 \% \mathrm{CI}^{\mathrm{z}}$ \\
\hline Treatment & 23 & $7-78$ \\
pH 6.5, control & 19 & $5-63$ \\
pH 3.0, control & 1256 & $381-4145$ \\
pH 6.5, leached & 68 & $21-224$ \\
pH 3.0, leached &
\end{tabular}

${ }^{\mathrm{z}}$ Confidence interval. ply ample amounts of $\mathrm{N}$ to sustain cranberry production throughout the season with no addition of $\mathrm{N}$ fertilizer. In mineral soils with organic carbon in excess of $1.5 \%, \mathrm{~N}$ release increases above $21.2^{\circ} \mathrm{C}$ and nutrient management should be adjusted accordingly. Recent research has shown that cranberries most effectively take up $\mathrm{N}$ between 18 and $24{ }^{\circ} \mathrm{C}$ (Roper et al., 2004). Thus, during periods of prolonged heat, less $\mathrm{N}$ fertilizer is needed as soil $\mathrm{N}$ release increases.

\section{Literature Cited}

Ben-Dor, E. and A. Banin. 1989. Determination of organic matter content in arid zone soils using a simple "loss-on-ignition" method. Comm. Soil Sci. Plant Anal. 20:1675-1695.

Carpenter-Boggs, L., J.L. Pikul, Jr., M.F. Vigil, and W.E. Riedel. 2000. Soil nitrogen mineralization influenced by crop rotation and nitrogen fertilization. Soil Sci. Soc. Amer. J. 64:2038-2045.

Cassman, K. and D. Munns. 1980. Nitrogen mineralization as affected by soil moisture, temperature, and depth. Soil Sci. Soc. Amer. J. 44:1233-1237.

Chantigny, M.H., D.A. Angers, and P. Rochette. 2002. Fate of carbon and nitrogen from animal manure and crop residues in wet and cold soils. Soil Biol. Biochem. 34:509-517.

Dana, M.N. 1990. Cranberry management, p. 334-362. In: G.L. Galletta and D.G. Himelrick (eds.). Small fruit crop management. Prentice Hall, Englewood Cliffs, N.J.

Davenport, J.R. 1996. The effect of nitrogen fertilizer rates and timing on cranberry yield and fruit quality. J. Amer. Soc. Hort. Sci. 12:1089-1094.

Davenport, J.R. and C.J. DeMoranville. 1993. A survey of several physical characteristics of cultivated cranberry bog soils in North America. Commun. Soil Sci. Plant Anal. 24: 1769-1773.

Davenport, J.R., C. DeMoranville, and P.C. Fletcher. 1994. Fertilizer mobility in cranberry soils. Cranberries 58:11-19.

Davenport, J.R. and N. Vorsa. 1999. Cultivar fruiting and vegetative response to nitrogen fertilizer in cranberry. J. Amer. Soc. Hort. Sci.124:90-94.

Davidsson, T.E. and M. Ståhl. 2000. The influence of organic carbon on nitrogen transformations in five wetland soils. Soil Sci. Soc. Amer. J. 64: 1129-1136.

DeMoranville, C. 1990. Cranberry bog soil pH: Historic and current relationship to yield. HortScience 25:1098. (Abstr.)

DeMoranville, C.J. 1992. Cranberry nutrients, phenology, and $\mathrm{N}-\mathrm{P}-\mathrm{K}$ fertilization. PhD Diss., Univ. of Massachusetts, Amherst.

DeMoranville, C.J. 1997. Cranberry nutrition and fertilizers, p. 78-82. In: H. Sandler (ed.). Cranberry cultivation: A guide for Massachusetts. Cranberry Expt. Sta. and Univ. Mass. Ext. Publ. SP-127.

Eck, P. 1990. The American cranberry. Rutgers Univ. Press, New Brunswick, N.J.

Environmental Protection Agency. 1984a. Methods for chemical analysis of water and wastes: $\mathrm{Ni}$ trogen ammonia. Method 350.1, STORET No. Total 00610, Dissolved 00608.

Environmental Protection Agency. 1984b. Methods for chemical analysis of water and wastes: Nitrogen nitrate-nitrite. Method 353.2, STORET No. Total 00630.

Franzluebbers, A.J., R.L. Haney, F.M. Hons, and D.A. Zuberer. 1996. Determination of microbial biomass and nitrogen mineralization following rewetting of dried soil. Soil Sci. Soc. Amer. J. 60:1133-1139. 
Griffin, T.S. and C.W. Honeycutt. 2000. Using growing degree days to predict nitrogen availability from livestock manures. Soil Sci. Soc. Amer. J. 64:1876-1882.

Hanlon, E.A., D.L. Anderson, and O.A. Diaz. 1997. Nitrogen mineralization in Histisols of the Everglades Agricultural Area. Commun. Soil Sci. Plant Anal. 28:73-87.

Korcak, R.F. 1989. Variation in nutrient requirements of blueberries and other califuges. HortScience 24:573-578.

Issac, R.A. and W.C. Johnson. 1976. Determination of total nitrogen in plant tissue using a block digestor. J. Assn. Offic. Anal. Chem. 59:98-100.

Lachat Instruments. 1995. Total Kjeldahl nitrogen in soil/plant. QuickChem Method 12-107-04 $1-\mathrm{B}$.

McInnes, K.J. and I.R.P. Fillery. 1989. Modeling field measurements of the effect of nitrogen source on nitrification. Soil Sci. Soc. Amer. J. 53:1264-1269.

Miller, W.P. and D.W. Miller. 1987. A micro-pipette method for soil mechanical analysis. Commun. Soil Sci. Plant Anal. 18:1-15.

Myers, R.G., C.W. Swallow, and D.E. Kissel. 1989. A method to secure, leach, and incubate undisturbed cores. Soil Sci. Soc. Amer. J. 53:467-471.

Roper, T.R., A.R. Kruger, C.J. DeMoranville, N. Vorsa, J. Hart, and A.P. Poole. 2004. Rate of ammonium uptake by cranberry (Vaccinium macrocarpon Ait.) vines in the field is affected by temperature. HortScience. (In press.)

Ruzicka, J. 1983. Flow injection analysis - From test tube to integrated microconduits. Anal. Chem. 55:1040A-1053A.

Schmidt, E.L. and L.W. Belser. 1994. Autotrophic nitrifying bacteria, p. 159-178. In: J.M. Bigham (ed.). Methods of soil analysis, Part 2: Microbio- logical and biochemical properties. Soil Sci. Soc. Amer. (SSSA) Press, Madison, Wis.

Smith, C.J., P.M. Chalk, D.M. Crawford., and J.T. Wood. 1994. Estimating gross nitrogen mineralization and immobilization rates in anaerobic and aerobic soil suspensions. Soil Sci. Soc. Amer. J. 58:1652-1660.

Smith, J.D. 1993. Uptake and utilization of nitrogen sources by cranberry plants (Vaccinium macrocarpon Ait.). PhD Diss., Univ. of Wisconsin, Madison.

Stenger, R., E. Priesack, and F. Beese. 1995. Rates of net nitrogen mineralization in disturbed and undisturbed soils. Plant Soil 171:323-332.

Stenger, R., E. Priesack, and F. Beese. 1996. In situ studies of soil mineral N fluxes: Some comments on the applicability of the sequential coring method in arable soils. Plant Soil 183. 199-211. 